\title{
Spatiotemporal variability of fire characteristics affect animal responses in pyric landscapes
}

\author{
Bradley S. Cohen ${ }^{1 *}$, Thomas J. Prebyl², Bret A. Collier ${ }^{3}$ and Michael J. Chamberlain ${ }^{2}$
}

\begin{abstract}
Background: Behavioral responses are the most immediate ways animals interact with their environment, and are primary mechanisms by which individuals mitigate mortality risk while ensuring reproductive success. In disturbancedriven landscapes, animals must adjust behaviors both spatially and temporally to maximize individual fitness. Prescribed fire is an important ecosystem driver in many coniferous forests, as fire cycles nutrients, creates spatially heterogeneous distributions in quantity and quality of forage and cover, and provides opportunities for fire-adapted taxa. Because fire immediately shifts resource distribution, and fire characteristics may drive behavioral responses to recent burns, we examined behavioral responses of 105 Global Positioning System (GPS)-tagged female eastern wild turkeys (Meleagris gallopavo silvestris Linnaeus, 1758) to fire application at three sites in southeastern United States. We used satellite-derived imagery to calculate burn severity and burn heterogeneity. We also calculated distance to adjacent unburned stands and time-since-fire at GPS locations of each turkey while inside burned stands. We used behavioral change point analyses to estimate behavioral state for turkeys using burned areas, and generalized linear mixed models to estimate how fire characteristics affected turkey behavior inside burned areas.

Results: Turkeys focused their use in less severely burned areas, and were less likely to use the interior of burned areas. Turkeys were more likely to forage and rest in less severely burned areas, suggesting that managers should apply prescribed fire frequently enough to promote low-severity burns. We found that, as distance to neighboring unburned areas increased, turkeys were more likely to walk through the interiors of recently burned areas, as opposed to resting or foraging in them, suggesting that the interiors of some burn units are less suitable habitat in the year that prescribed fire is applied. Our findings suggest that prescribed fire applied to ensure that interior areas of burned stands are $<250 \mathrm{~m}$ from adjacent unburned stands or to stands shaped to maximize edge-to-area ratios likely create more suitable conditions for foraging and resting.

Conclusions: The application and spatial arrangement of prescribed fire, even in frequently burned areas, affect animal response and behaviors. Prescribed fire regimes should be created in recognition that sizes of burned stands and fire severity, along with determinants of fire severity (e.g., fuel loads, return intervals, timing), are important influences on animal behavior in frequent-fire-managed landscapes.
\end{abstract}

Keywords: animal response, behavioral state, burn severity, change point analysis, conifer, disturbance, landscape conservation, Meleagris gallopavo, Pinus spp., prescribed fire

\footnotetext{
* Correspondence: bcohen@tntech.edu

'Department of Biology, Tennessee Technological University, 1100 N Dixie

Avenue, Cookeville, TN 38505, USA

Full list of author information is available at the end of the article
} 


\section{Resumen}

Antecedentes: Las respuestas en el comportamiento son las formas más inmediatas en que los animales interactúan con su ambiente, y son mecanismos primarios por medio de los cuales los individuos mitigan riesgos de mortalidad mientras aseguran su éxito reproductivo. En paisajes disturbados, los animales deben ajustar sus comportamientos, tanto espaciales como temporales para maximizar su adaptación individual. Los fuegos prescriptos son importantes promotores de cambios en ecosistemas de bosques de coníferas, dado que el fuego recicla los nutrientes, crea distribuciones espaciales heterogéneas de forraje en cantidad, calidad y cobertura, y provee oportunidades para el establecimiento de taxones adaptados al fuego. Dado que el fuego cambia inmediatamente la distribución de los recursos, y las características del fuego pueden producir respuestas de comportamiento en quemas recientes, examinamos respuestas de comportamiento de 105 pavos silvestres orientales hembras (Meleagris gallopavo silvestris Linnaeus, 1758), marcados con tarjetas acopladas a un sistema de posicionamiento global GPS, después de la aplicación de quemas prescriptas en tres sitios en el sudeste de los EEUU. Utilizamos imágenes satelitales para calcular la severidad y la heterogeneidad de la quema. También calculamos la distancia a sitios adyacentes sin quemar, y el tiempo pasado desde el inicio del fuego en ubicaciones del GPS de cada pavo mientras estuvieron en los rodales quemados. Utilizamos análisis puntuales de comportamiento de los pavos que utilizan áreas quemadas y modelos generalizados mixtos para estimar como las características del fuego afectaron el comportamiento de los pavos dentro de las áreas quemadas.

Resultados: Los pavos enfocaron el uso en áreas menos severamente quemadas, y fue menos probable que usaran el interior de áreas quemadas. Los pavos tuvieron la tendencia a alimentarse y descansar en sitios menos severamente quemados, sugiriendo que los gestores deberían aplicar quemas prescriptas con la suficiente frecuencia para promover quemas poco severas. Encontramos que a medida que la distancia hacia lugares vecinos sin quemar aumentaba, era más probable que los pavos caminaran hacia el interior de algunas áreas recientemente quemadas, en contraposición con descansar o alimentarse en ellos, lo que sugiere que los interiores de algunos sitios quemados son hábitats menos adecuados en el año en que la quema prescripta fue aplicada. Nuestros hallazgos sugieren que la quema prescripta aplicada para asegurar que el interior de los rodales quemados estén a menos de $250 \mathrm{~m}$ de rodales adyacentes no quemados, o de rodales modelados para maximizar la relación de borde/área, crean probablemente condiciones más adecuadas para alimentarse y descansar.

Conclusiones: La aplicación y el arreglo espacial de quemas prescriptas, aún en áreas frecuentemente quemadas, afecta la respuesta animal y sus comportamientos. Los regímenes de quemas prescriptas deberían ser creados reconociendo que el tamaño de los rodales quemados y la severidad del fuego, junto con determinantes de la severidad del fuego (por ej. cargas de combustible, intervalos de retorno, tiempos), influencian de modo importante el comportamiento animal en paisajes manejados con fuegos frecuentes.

\section{Background}

Prescribed fire is an ecosystem driver in southeastern USA coniferous forests, where fire leads to spatially heterogeneous distributions in quantity and quality of forage and cover depending on the characteristics of the fires. The ecological effects of fire depend on burn severity (Key and Benson 2006; Elliott et al. 2009), frequency (Haywood 2012), heterogeneity in burn severity across a burned stand (Hayes and Robeson 2011; Parkins et al. 2018), fire size (Baker 1993; Key and Benson 2006), and time-since-fire (Harrod et al. 2000, Hurteau et al. 2008, Elliott et al. 2009), which in turn dictate vegetation responses (Kirkman et al. 2004; Elliot et al. 2009; Wiggers et al. 2013). In pine (Pinus L. spp.)-dominated forests of southeastern United States, vegetation responses to fire are dynamic, and variation in fire characteristics influences survival of understory plants, germination of herbaceous plants, and future vegetation conditions
(Thaxton and Platt 2006; Ellair and Platt 2013; Wiggers et al. 2013).

A central question in ecology is the role that components of disturbance (e.g., distribution, frequency, size, severity; White and Pickett 1985) play in affecting resource availability and animal response (Wong and Candolin 2015). In pyric landscapes, animal responses post fire are driven by vegetation structure and composition within the post-burn stand, and resources provided by burned and neighboring unburned stands (Dunning et al. 1992; Madden et al. 1999; Briani et al. 2004). Vegetation communities in southeastern United States shift rapidly post fire (Glitzenstein et al. 2012; Haywood 2012), from predominately bare ground immediately after fires (Jones et al. 2013), to grass- and forbdominated understories during the first growing season (Kirkman et al. 2004). After one growing season post fire, hardwood stems increase in the midstory and 
overstory (Provencher et al. 2001; Beckage et al. 2009; Haywood 2012), decreasing the prominence of forbs and grasses, unifying structural heterogeneity in the understory (Kush et al. 2000; Varner et al. 2000), and decreasing understory vegetation diversity (Glitzenstein et al. 2012). Thus, vegetation differences between burned and unburned areas are most distinct the first year post fire (Varner et al. 2000; Provencher et al. 2001; Beckage et al. 2009) and, as time progresses, burned areas can converge in habitat suitability for some species, as vegetation communities more closely mirror surrounding unburned areas (Provencher et al. 2001, Beckage et al. 2009).

The eastern wild turkey (Meleagris gallopavo silvestris Linnaeus, 1758; hereafter, turkey) inhabits pinedominated ecosystems in southeastern United States that are frequently managed with prescribed fire. Recent evidence suggests that turkeys select for recently burned ( $\leq 2 \mathrm{yr}$ post burn) pine stands within these landscapes (Yeldell et al. 2017a; Yeldell et al. 2017b, 2017c; Wood et al. 2018). Herbaceous vegetation comprises a substantial component of turkey diets (Exum et al. 1987; Hurst 1992), and changes in groundcover vegetation (Wiggers et al. 2013), herbaceous plants (Ellair and Platt 2013), and invertebrates (New 2014) after prescribed fire may shift forage availability (Campo et al. 1989; Burk et al. 1990; Sisson et al. 1990; Still and Bauman 1990). Likewise, sparse understory immediately following prescribed fire but before plant regrowth (Lavoie et al. 2010), coupled with decreases in midstory structure, may shift available concealment and escape cover (Andersson et al. 2009). Additionally, female turkeys inhabiting landscapes in southeastern United States that are managed with prescribed fire encounter a dynamic landscape as fire events occur concurrent with reproductive efforts (Yeldell et al. 2017a; Wood et al. 2018). Females maintaining ranges that encompass fire-affected stands must find areas within burned patches that optimize forage intake, during and after the processes of egg laying, incubation, and postnesting behaviors (Dickson 1992; Palmer and Hurst 1998). Therefore, females must immediately assess spatial shifts in resource availability post fire and alter their behavior to increase relative fitness (Candolin and Wong 2012).

Behavioral responses of wild turkeys to prescribed fire may be driven by the temporal and spatial redistribution of resources within the landscape, and the availability of vegetation communities near, but not influenced by, fire activity. Because prescribed fire immediately alters vegetation communities, and is applied during winter, spring, and summer, which coincides with the reproductive period of wild turkeys, it has the potential to alter fitness in turkey populations (Yeldell et al. 2017a). However, fire characteristics (i.e., burn severity, time-since-fire, etc.) influence vegetation response, affecting availability of both forage and cover, and may mediate turkey response immediately following prescribed fire application. Therefore, our objectives were to examine female turkey use of pine stands managed with prescribed fire to assess what fire characteristics impact patterns of use and behavior following fire application. Specifically, we examined how time-since-fire, burn severity, burn heterogeneity, and distance to nearest unburned stand affected turkey use and behaviors in recently burned pine stands. We hypothesized that burned areas would be more likely to be used by turkeys as time-since-fire increased because of increased forage availability. We also hypothesized that turkeys would be more likely to use the edge of burned areas because it provided closer proximity to escape cover, and turkeys would be less likely to use areas of higher burn severity and lower burn heterogeneity because these conditions would decrease forage availability and escape cover. We hypothesized that turkeys would be more likely to forage and rest in areas with lower burn severity and increased time-since-fire because of increases in forage availability, while they were likely to engage in walking behaviors in more severely burned areas and in locations farther from non-burned stands.

\section{Methods}

\section{Study area}

We conducted research on three study sites dominated by pine forest communities managed extensively with prescribed fire to manipulate vegetation composition, structure, and understory communities (Additional file 1). We conducted research on the Kisatchie National Forest (KNF) and Fort Polk Wildlife Management Area (WMA) in west-central Louisiana, USA $\left(31.122475^{\circ},-93.172794^{\circ}\right)$, during 2014 to 2015 . The KNF was owned and managed by the United States Forest Service (USFS), whereas Fort Polk WMA was jointly owned by the USFS and the United States Army. Sites were composed of pinedominated forests, hardwood riparian zones, and forested wetlands, with forest openings, utility right-of-ways, and forest roads distributed throughout. Primary overstory species included longleaf pine (Pinus palustris Mill.), loblolly pine (P. taeda L.), oaks (Quercus L. spp.), hickories (Carya Nutt. spp.), and red maple (Acer rubrum L.). Average size of burn patches on KNF was 485 ha $(\mathrm{SD}=295$ ha) but ranged from 7 to 1567 ha. In 2014 and 2015, the proportion of land burned within the KNF and Fort Polk WMA study areas was $23.2 \%$ and $19.2 \%$, respectively. Prescribed fire was applied in both dormant seasons (December to March) and growing seasons (April to July), with most fires (71.3\% of total area burned) applied in dormant seasons. Stands were managed with fire return intervals ranging from 3 to $5 \mathrm{yr}$, although some pine-dominated areas had no recent burn 
history at the time of our study. For a detailed description of site conditions on KNF and Fort Polk WMA, see Yeldell et al. (2017a).

During 2015 to 2016, we conducted research on the Silver Lake Wildlife Management Area (30.818734 ${ }^{\circ}$, $\left.-84.740749^{\circ}\right)$, owned and managed by the Georgia Department of Natural Resources-Wildlife Resources Division (GADNR), and the Lake Seminole Wildlife Management Area, owned by the US Army Corps of Engineers and managed by GADNR in southwest Georgia, USA (collectively hereafter referred to as SLWMA). The SLWMA was dominated by mature pine forests and forested wetlands. Overstory species were predominately longleaf pine, loblolly pine, slash pine (Pinus elliottii Engelm.), oaks, and sweetgum (Liquidambar styraciflua L.). The proportion of land within the study area burned annually was $22.5 \%$ in 2015 , and $25.7 \%$ in 2016. Prescribed fire was applied throughout the year on SLWMA but most fires occurred during the dormant season in 2015 (63.3\%) and growing season in 2016 (92.3\%). Average size of burns on SLWMA was $26 \pm 3.7$ ha (range: 3 to 72 ha) in 2015, and $20 \pm 2.5$ ha (range: 1 to 73 ha) in 2016. Prescribed fire was applied on an approximately 2- to 4-year return interval. For a detailed description of site conditions on Silver Lake Wildlife Management Area, see Wood et al. (2018).

During 2014 to 2016, we conducted research on three contiguous wildlife management areas (Webb, Hamilton Ridge, and Palachucola; hereafter Webb WMA Complex) in South Carolina, USA, all managed by the South Carolina Department of Natural Resources (SCDNR). The Webb WMA Complex (32.589718 ${ }^{\circ}$, $-81.310642^{\circ}$ ) was dominated by longleaf, loblolly, and slash pine forests with hardwood stands along riparian corridors, and expanses of bottomland hardwood wetlands. The average size of burn patches on Webb WMA Complex during our study was 57 ha (SD $=58$ ha) but ranged from 2 to 353 ha. The proportion of land within the study area burned annually was $18.2 \%$ in $2014,13.5 \%$ in 2015 , and $11.6 \%$ in 2016. Prescribed fire was applied from January to August, with $47.2 \%$ of burns occurring during the dormant season. Prescribed fire was applied on an approximately 3- to 5-year return interval. For a detailed description of site conditions on the Webb WMA Complex, see Wightman et al. (2019).

\section{Animal capture, Global Positioning System locations, and availability of burned stands}

We captured female turkeys using rocket nets during January to March of 2014 to 2017. We fitted turkeys with a serially numbered, butt-end style or riveted aluminum tarsal band and a backpack-style Global Positioning System (GPS) transmitter (Guthrie et al. 2011) equipped with a VHF (Very High Frequency) beacon and mortality sensor weighing approximately $88 \mathrm{~g}$ (Lotek Minitrack Backpack L; Lotek Wireless Inc., Newmarket, Ontario, Canada). We programmed GPS transmitters to record hourly locations from 0500 to 2000 local time each day, and one nightly roost location at 23:59:58, between 1 March and 31 July (Cohen et al. 2018). We chose these dates because they coincide with the traditional timing of the reproductive season on our sites, when flocks have broken up and individual females are usually separate from other females (Yeldell et al. 2017a; Wood et al. 2018; Wightman et al. 2019). All birds were released on site immediately after processing.

We used a hand-held, three-element Yagi antenna and R2000 or R4000 receiver (Advanced Telemetry Systems, Inc., Isanti, Minnesota, USA) to locate and monitor the status of radio-marked individuals $\geq 1$ time per week. We assumed onset of nest incubation when GPS locations were fixed around a central point for at least 24 hours (Yeldell et al. 2017a) and monitored incubating females daily using radio telemetry. When GPS locations indicated that females left the nest and did not return for $>24$ hours, we assumed that the female had stopped incubating. We then located the nest using GPS coordinates to determine nest fate and recorded the dates of nest initiation and nest termination.

To determine what percentage of radio-marked turkeys may have had burned stands available to them, we generated a $100 \%$ minimum convex polygon $(\mathrm{MCP})$ around all recorded GPS locations of each turkey and identified all turkeys whose MCP intersected $\geq 1$ burned area. We assumed that any burned area within a turkey's MCP was available to that individual (Yeldell et al. 2017c).

\section{First passage time}

Understanding the influence of environmental factors on behavior is a central question in movement ecology. However, assessing environmental factors at inappropriate spatial scales can bias inferences, particularly when attempting to understand animal responses to changing landscapes (Lai et al. 2015; Bissonette 2017). Scale issues can be minimized by using movement data to inform the biologically relevant scales used by animals (Byrne et al. 2014). We estimated first passage time (FPT) values to quantify the scale of activity at the individual level, which provides an accurate assessment of the scale at which individuals react to their environment (Bissonette 2017). First passage time is defined as the time it takes an animal to move through a circle of a given radius $r$ centered on a given point, and provides inferences about animal behavior when measured at 
evenly spaced points along a movement trajectory (Fauchald and Tveraa 2003).

Following the methodology of Byrne et al. (2014) to estimate the scale at which female turkeys perceived and reacted to stimuli within their environment, we interpolated times and locations at $1 \mathrm{~m}$ intervals along daily movement paths, and calculated FPT centered on these locations for circles with radius $r$ ranging from $10 \mathrm{~m}$ to $400 \mathrm{~m}$ in $10 \mathrm{~m}$ increments. For each path, we extracted the value of $r$ associated with the greatest variance in log-transformed FPT values, which indicated the scale at which a turkey was concentrating its activities (Fauchald and Tveraa 2003). Because scale varied across individual paths, we defined a common scale for analysis using the largest mean variance averaged across all paths for each individual $(76.12 \mathrm{~m})$. Because this is the scale at which the variance was most pronounced, we offer that it also is the scale at which behavioral responses were influenced by environmental stimuli, and at which the greatest effect sizes should occur. As such, we quantified covariates associated with prescribed fire (described below) by calculating mean values within a $76.12 \mathrm{~m}$ buffered circle around each GPS location, and used these values for subsequent analyses.

\section{Burn characteristic covariates}

\section{Burn severity and heterogeneity}

Burn severity influences vegetation communities (Gagnon et al. 2015), and may ultimately influence how animals are able to acquire resources after fires occur. Burn severity affects survival of midstory and canopy plants, and heterogeneity in burn severity promotes diversity in understory plant growth, woody plant stem density, germination of legumes and grasses, and vertical and horizontal structure (Brockway and Lewis 1997; Thaxton and Platt 2006; Grady and Hoffmann 2012). Prescribed fire can produce patchy outcomes (Penman et al. 2007), and the degree of vegetation removal directly influences the spatial distribution of resources and predator communities. Hence, these resulting changes affect forage availability and predation risk, and habitat quality may differ across burned areas based on burn severity and burn heterogeneity. Therefore, we examined how burn severity and heterogeneity affected turkey behavior within burned areas.

To quantify burn severity and heterogeneity, we first obtained spatial data displaying history of prescribed fire application across our study areas from land management agencies (USFS, state agencies, and private timber companies). We used these data to create polygons of fire events that occurred during our study period. To assess burn severity of prescribed fires, we used the USGS Landsat 5, 7, and 8 Surface Reflectance Tier 1 collections
(Masek et al. 2006), which we accessed via Google Earth Engine (Gorelick et al. 2017). From these collections, we selected all available Landsat scenes from 2011 to 2017 that had $<50 \%$ cloud cover for each study area. We used the radiometric saturation and pixel quality bands to mask any scene pixels that were saturated or not classified as Clear, low-confidence cloud or Clear, mediumconfidence cloud (Ernst et al. 2018). We then computed the normalized burn ratio (NBR) for all scenes and unmasked pixels in our collection. Normalized burn ratio is the ratio of between Landsat bands that are sensitive to vegetation cover and exposed soil cover (bands 4 and 7 in Landsat 5 and 7; bands 5 and 7 in Landsat 8). Therefore, we calculated NBR using the following formulas:

$$
\text { Landsat } 5 \text { and } 7 N B R=\frac{(\text { Band } 4-\text { Band } 7)}{(\text { Band } 4+\text { Band } 7)}
$$

$$
\text { Landsat } 8 N B R=\frac{(\text { Band } 5-\text { Band } 7)}{(\text { Band } 5+\text { Band } 7)}
$$

Next, we processed each burn polygon to determine if suitable pre-fire and post-fire Landsat scenes were available to calculate a differenced Normalized Burn Ratio (dNBR) of the burn (Miller and Thode 2007; Picotte and Robertson 2011). Difference Normalized Burn Ratio is calculated by subtracting the post-fire NBR image from the prefire (unburned) NBR image, and is used to identify the severity of changes resulting from fire (Miller and Thode 2007; Picotte and Robertson 2011). It has been used successfully for evaluating response of wild turkeys to wildfire (Oetgen et al. 2015). Following recommendations of Picotte and Robertson (2011), we limited pre-burn scenes to those collected $\leq 2 \mathrm{yr}$ prior to the burn and within a \pm 30 -day window of the burn. We limited post-burn scenes to those that occurred 2 to 8 weeks following the burn date. For all burns with suitable Landsat imagery, we exported a $30 \mathrm{~m}$ raster layer containing dNBR values for each burn (Fig. 1). In instances where multiple pre- or post-burn scenes were available, we calculated the average pre:post burn NBR values prior to calculating the difference. For our estimates, $2.0 \mathrm{dNBR}$ was the maximum possible estimate of burn severity, with values closer to zero representing less burn severity. Negative values represented unburned areas and were therefore excluded from our analyses (Picotte and Robertson 2011).

\section{Distance to nearest unburned stand}

Prescribed fire removes vegetation and thatch and stimulates new vegetation growth, which creates ideal foraging 


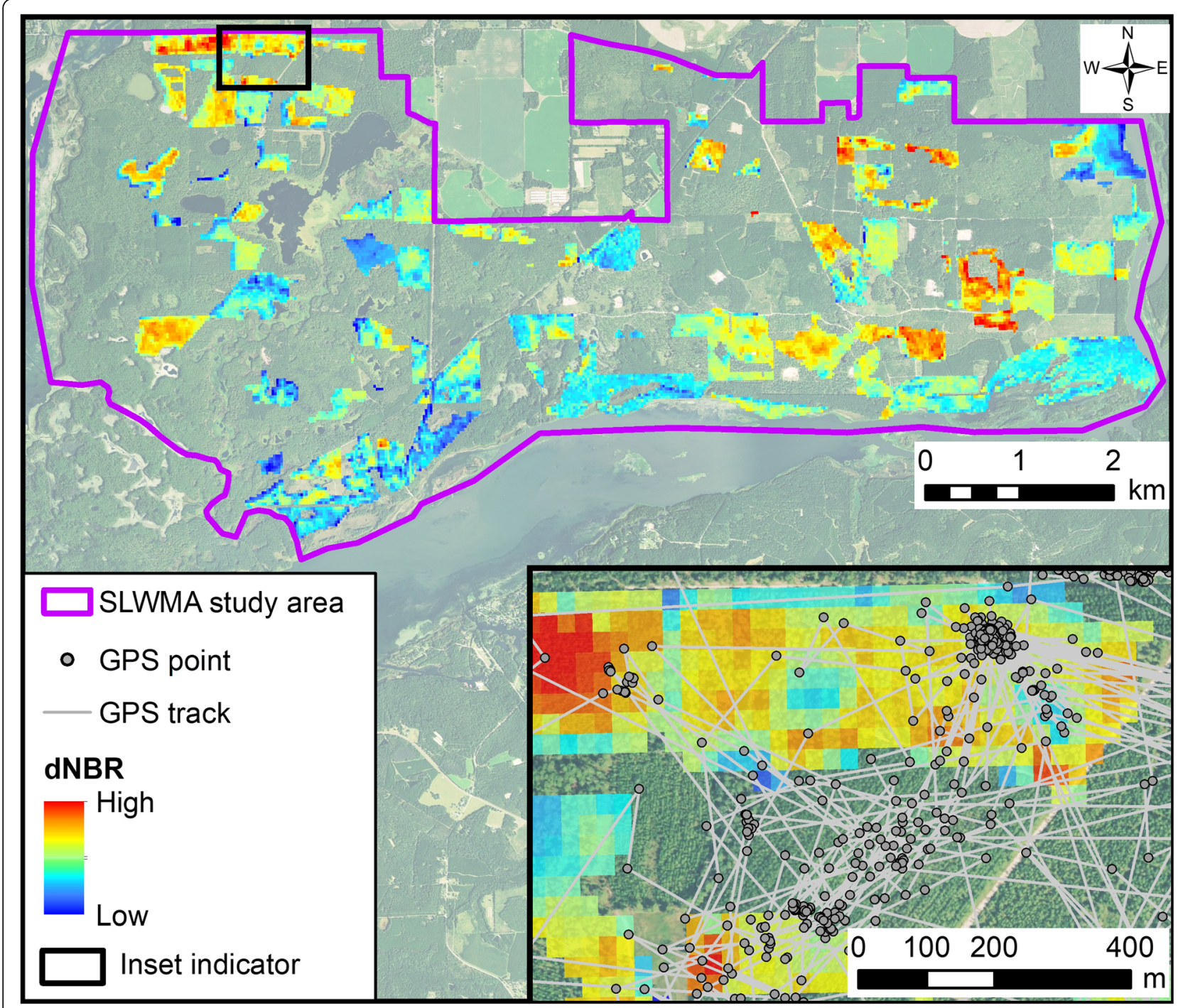

Fig. 1 The differenced Normalized Burn Ratio (dNBR) for all burns in a single year (2015) at one study site (SLWMA; Silver Lake Wildlife Management Area in Georgia, USA). For all burns with suitable Landsat imagery, we exported a $30 \mathrm{~m}$ raster layer containing dNBR values for each burn during our study period. Inset: part of one individual female eastern wild turkey's (Meleagris gallopavo silvestris) GPS track showing use of burned and unburned areas

habitat for turkeys (Healy 1992). However, prescribed fire temporarily removes structure that provides visual obstruction and thermal refuge; hence, turkeys may need access to unburned stands that provide those resources. Landscape complementation hypotheses suggest that animals that require resources found in different vegetation communities will have their greatest populations in landscapes where these communities are juxtaposed (Dunning et al. 1992). Recent evidence suggests that turkeys may use the interface between burned and unburned areas as complementary patches to balance food availability and proximity to escape cover (Yeldell et al. 2017c). Because the size and juxtaposition of fires within the landscape potentially affects distance between vegetation communities that provide different resources and turkey response in burned areas, we assessed if turkeys constrained their behavioral responses in proximity to unburned areas. For each GPS location, we calculated distance to the nearest unburned stand. We considered recently burned stands to be any forest stand $\leq 250$ days post burn. We considered an unburned stand to be any forest stand that was not burned in the same calendar year that an individual turkey was monitored, or that had no known burn history. Although unburned stands could have been burned previously or had a history of prescribed fire application, vegetation communities converge rapidly post 
burn on our study sites (Haywood 2009, 2010). Therefore, we treated all stands $\geq 1$ yr post burn as unburned stands, as our objective was to assess behavioral responses of turkeys to fire within the same growing season as fire application.

\section{Days-since-fire}

Because vegetation cover is lowest immediately following a burn but increases through time (Jones et al. 2013), time-since-fire may affect turkey response to recently burned stands (Kilburg et al. 2014; Yeldell et al. 2017b, 2017c). We updated fire history maps daily, which allowed the landscape that a turkey encountered to change daily as fires occurred, and allowed us to identify if a turkey used an area $\geq 1$ day post burn. We calculated the associated time-sincefire value for all locations as time (days) lapsed between the GPS location date and the prescribed fire application.

Using burn polygons and Landsat dNBR scenes, we created a daily landscape of time-since-fire and burn severity. From this data set, we calculated the following for each turkey GPS location within a burn polygon: timesince-fire (days), distance to unburned stand ( $\mathrm{m}$ ), burn severity (mean dNBR within FPT radius), and burn heterogeneity (variance $\mathrm{dNBR}$ within FPT radius). Because we were interested in turkey responses to fire during the year of fire application, we excluded any location with a negative time-since-fire value or a timesince-fire value $>250$ days.

\section{Behavioral states}

We quantified how turkeys behaved in burned areas and what fire characteristics affected behaviors. We modeled turkey behavior using behavioral change point analysis (BCPA; Gurarie et al. 2009), a likelihood-based method allowing identification of changes in movement parameters underlying locational time-series data. The BCPA uses a sweeping window analysis and temporal autocorrelation associated with telemetry locations to detect changes in movement parameter values, specifically velocities and relative turn angles (RTAs), and then estimates the most likely change point (i.e., location where shift in movement parameters occur) within each window according to a Bayesian Inference Criterion (BIC; Gurarie et al. 2009). We used BCPA to identify and interpret movement behaviors because it can reveal behavioral structure in animal-tracking data without any prior assumptions regarding the distributions of movement parameters (Gurarie et al. 2009, 2016).

We calculated velocity and RTA between all sequential locations for the full path collected for each turkey. We used a smoothed BCPA analysis in R ( R
Core Team 2017) package bcpa (Gurarie 2014), and tuned our analysis using a window size of 30 sequential locations and sensitivity (K) of 1 (Gurarie 2014; Gurarie et al. 2016). These settings allowed us to identify changes in behavior at the smallest temporal scale possible while still meeting the minimum sample size required for BIC model selection (Gurarie et al. 2009). We hereafter refer to segments of trajectories between the change points identified by BCPA as bouts. Because the distribution of velocity and RTA values were positively skewed, we calculated median values for these metrics.

We assessed within-group sum of squares and serial classification of bouts using Krzanowski and Lai's (1988) hierarchical clustering method to determine the number of distinct behavioral states for each turkey based on combinations of median velocity and RTA (Zhang et al. 2015). Specifically, we used $k$ means clustering (Hartigan and Wong 1979) in packages cluster (Maechler et al. 2017) and fpc (Hennig 2018) to classify movement bouts into mutually exclusive behavioral states based on combinations of median velocity and RTA. This allowed us to categorize bouts identified by BCPA into unique behavioral states based on similarities in patterns of movement, but the number of unique behavioral states for each individual could vary based on $k$ means clustering. We chose to limit our $k$-means clustering to three behavioral states (Zhang et al. 2015). These behavioral states were 1) an arearestricted search behavior, in which movements would have higher RTA but lower velocities, presumably as turkeys searched and foraged; 2) a resting behavior, in which movements would have lower RTA and lower velocities, presumably as turkeys "loafed;" and 3) a directional movement behavior, in which movements would have lower RTA but higher velocities, as presumably turkeys walked through an area (Additional file 2; Zhang et al. 2015; Gurarie et al. 2016). We then assigned each GPS location to its appropriate behavioral state.

Because we were interested in how turkey behaviors potentially changed within burned stands relative to when they used all areas within their ranges, we evaluated how turkey behaviors differed outside and inside burned stands. To discern these differences, we calculated the proportion of locations spent in each behavioral state for each female, and then calculated the mean and standard error of these proportions across females. We then described behavior within burned areas by calculating the proportion of locations in each behavioral state for each female while they were inside burned areas, and then calculated the mean and standard error of these proportions across females. 


\section{Distribution of use in recent burns}

We examined if time-since-fire, burn severity, burn heterogeneity, and distance to unburned stand influenced the spatial distribution of turkey locations within burned stands. For each turkey that used a burned area, we counted numbers of locations within a particular burn stand following fire application and generated three random locations within the same stand (Northrup et al. 2013). All three random locations were associated with a single used location and shared the same time-since-fire value. For turkeys that used multiple burned areas, we generated separate sets of random locations within each unique burn stand used. For each random and used location, we then calculated the time-since-fire, distance to nearest unburned stand, burn severity, and burn heterogeneity.

\section{Statistical analyses}

Because wild turkeys are a diurnal species and we were only interested in behavior when turkeys were active, we removed all roost locations and locations for females that were incubating nests. Prior to constructing models, we scaled some covariates to ease iteration of the likelihood and aid model convergence. We calculated Pearson correlation coefficients (r; Dormann et al. 2013) between explanatory variables and variance inflation factors prior to model fitting, and removed any variables that were correlated $|\mathrm{r}| \geq 0.7$ or variance inflation factors $>4$. (Zuur et al. 2009; Dormann et al. 2013).

We conducted generalized linear mixed modeling (GLMM) analyses using package lme4 (Bates et al. 2015) in program R v.3.3.3 ( $\mathrm{R}$ Core Team 2017) to investigate the explanatory power of fire characteristics on distribution of use and behaviors of turkeys within burned areas. We modeled distribution of use within burned stands using a generalized linear model with a binary response variable wherein we treated known turkey locations as a 1 and random locations as 0 . We modeled how fire characteristics affected the probability of a behavioral state by analyzing three separate models wherein we assigned the behavioral state of interest (e.g., walking) as 1 and all other states (e.g., foraging and loafing) as 0 . We treated time-since-fire, burn severity, burn heterogeneity, and distance to unburned stand as continuous predictor variables. We included a unique turkey identifier (Turkey ID) as a random effect to account for individual variability in response. Because our data collection coincided with flock breakup and turkey reproductive season on our sites (Yeldell et al. 2017a; Wood et al. 2018; Wightman et al. 2019), we expected that female behaviors would be driven by their focus on survival and reproduction, rather than on being part of a social group. Therefore, a random effect of "group" was not necessary. Because we were interested in how each covariate affected turkey responses, we estimated effect sizes using a single, full additive effects model for each of our analyses (Whittingham et al. 2006).

\section{Results}

We captured 153 female turkeys, 121 (79\%) of which had burned areas available to them. Of these 121 turkeys, 105 (87\%) were located within recently burned areas (Additional file 1). We recorded locations of 15 (14.2\%) females inside a burned area on the day of fire application, 25 (23.8\%) 1 day post burn, 31 (29.5\%) 2 days post burn, and 88 (83.8\%) within 30 days post burn. The number of locations collected per individual female ranged between 298 to 3295 .

\section{Use within recently burned areas}

No covariates were excluded due to collinearity. Probability of use was affected by time-since-fire, burn severity, and distance to unburned stands (Table 1; Fig. 2). Turkeys were less likely to use areas with higher burn severity and areas farther from unburned stands. For example, the probability of turkeys using burned areas declined as distance to adjacent unburned stands increased, decreased by $50 \%$ between 0 to $250 \mathrm{~m}$ from unburned stands, and declining to almost zero use after $600 \mathrm{~m}$. As time-since-fire increased, turkeys were less likely to use burned areas, although the decreases in probability of use were relatively small. Burn heterogeneity did not affect use.

\section{Behavior within recently burned areas}

All turkeys exhibited three distinct modes of behavior in their movement trajectories (Fig. 3). Behavioral state 1 was characterized by fast (median velocity = $211.63 \pm 39.96 \mathrm{~m} \mathrm{hr}^{-1}$ ) and comparatively straight (median RTA $\left.=53.17 \pm 6.87^{\circ}\right)$ movement trajectories. We interpreted this behavior as a directional movement and considered individuals in this state to be walking. Behavioral state 2 had slow velocities (median velocity $=64.10 \pm 12.55 \mathrm{~m} \mathrm{hr}^{-1}$ ) and low turn angles $\left(\right.$ median RTA $\left.=34.14 \pm 5.63^{\circ}\right)$. We interpreted this to be a resting behavior, and considered individuals in this state to be loafing. Behavioral state 3 was comparatively slow velocity (median velocity $=98.42 \pm 13.64 \mathrm{~m} \mathrm{hr}^{-1}$ ) but highly tortuous $\left(\right.$ median $\left.\mathrm{RTA}=124.44 \pm 9.36^{\circ}\right)$. We interpreted this as an area-restricted search behavior, and considered individuals in this state to be foraging. The proportion of time spent in each of the three behavioral states varied widely across movement trajectories of individual females. When evaluating behavioral states 
Table 1 Parameter estimates ( $\beta$; logit scale) for models examining how fire characteristics affect female eastern wild turkeys (Meleagris gallopavo silvestris) distribution of use and behaviors (i.e., foraging, loafing, and walking) within recently burned (i.e., $\leq 250$ days post burn) areas. Standard errors (SE), Z values, and probabilities that a coefficient differs from 0 are also presented. Data were collected from GPS-tagged wild turkeys at Silver Lake Wildlife Management Area in Georgia, Webb Center Complex in South Carolina, and Kisatchie National Forest in Louisiana, USA, between 1 March and 31 July, from 2014 to 2017

\begin{tabular}{|c|c|c|c|c|c|}
\hline$\overline{\text { Model }}$ & Covariate & $\beta^{a}$ & SE & $z$ & $P$ \\
\hline \multicolumn{6}{|c|}{ Distribution of use } \\
\hline & Intercept & 0.067 & 0.021 & 39.92 & $<0.01$ \\
\hline & Time-since-fire & -0.060 & 0.028 & -27.72 & $<0.01$ \\
\hline & Burn severity & -1.723 & 0.973 & -16.32 & $<0.01$ \\
\hline & Burn heterogeneity & 0.119 & 0.069 & 3.77 & 0.34 \\
\hline & Distance to unburned stand & -0.525 & 0.227 & -22.50 & $<0.01$ \\
\hline & Turkey ID ${ }^{b}$ & 0.190 & NA & NA & NA \\
\hline \multicolumn{6}{|c|}{ Behavioral state } \\
\hline \multicolumn{6}{|c|}{ Foraging } \\
\hline & Intercept & -0.488 & 0.091 & -14.978 & $<0.01$ \\
\hline & Time-since-fire & -0.052 & 0.030 & -1.706 & 0.09 \\
\hline & Burn severity & -1.743 & 0.444 & -2.634 & 0.04 \\
\hline & Burn heterogeneity & 0.451 & 0.136 & 3.288 & $<0.01$ \\
\hline & Distance to unburned stand & -0.191 & 0.018 & -2.799 & $<0.01$ \\
\hline & Turkey ID & 0.275 & NA & NA & NA \\
\hline \multicolumn{6}{|c|}{ Loafing } \\
\hline & Intercept & -0.222 & 0.095 & 2.329 & $<0.01$ \\
\hline & Time-since-fire & 0.201 & 0.021 & 7.055 & $<0.01$ \\
\hline & Burn severity & -0.432 & 0.215 & -3.080 & 0.04 \\
\hline & Burn heterogeneity & -0.649 & 0.064 & -1.010 & 0.31 \\
\hline & Distance to unburned stand & -0.001 & 0.016 & -0.089 & 0.93 \\
\hline & Turkey ID ${ }^{\mathrm{b}}$ & 0.570 & NA & NA & NA \\
\hline \multicolumn{6}{|c|}{ Walking } \\
\hline & Intercept & -1.534 & 0.135 & -11.396 & $<0.01$ \\
\hline & Time-since-fire & -0.319 & 0.041 & -7.860 & $<0.01$ \\
\hline & Burn severity & 0.702 & 0.183 & 4.761 & 0.01 \\
\hline & Burn heterogeneity & -0.189 & 0.080 & -2.337 & 0.02 \\
\hline & Distance to unburned stand & 0.085 & 0.025 & 2.239 & 0.03 \\
\hline & Turkey ID ${ }^{b}$ & 0.837 & NA & NA & NA \\
\hline
\end{tabular}

${ }^{a}$ Variables are scaled to aid model convergence. Distance to unburned stand was divided by 100 , time-since-fire (days) was divided by 50 , and burn heterogeneity was multiplied by 100 . Parameter estimate on logit scale

${ }^{\text {b}}$ Turkey ID was considered to be a random effect in the model. Thus, it is an estimate of standard deviation of the random effect term

across the entire sample of turkeys, including locations inside and outside burned areas, walking accounted for $12.6 \pm 0.5 \%$ of individual locations (range $=6.3$ to $24.3 \%$ ), loafing accounted for $62.3 \pm$ $0.4 \%$ (range $=47.7$ to $73.2 \%$ ), and foraging accounted for $25.2 \pm 0.2 \%$ (range $=15.3$ to $34.9 \%$ ). However, behavioral states changed when turkeys used burned areas; $22.5 \pm 2.6 \%$ of individuals' locations that fell in burned areas were walking, $42.4 \pm 1.5 \%$ were loafing, and $35.1 \% \pm 1.9$ were foraging.
Fire characteristics affected turkey behavior when using burned areas (Table 1). As time-since-fire increased, turkeys were less likely to engage in walking behaviors (Fig. 4), but more likely to loaf (Fig. 5). For example, probability of walking decreased by half between 0 to 250 days post fire, but probability of loafing nearly doubled. Time-since-fire did not affect the probability of turkeys foraging. Turkeys were more likely to walk (Fig. 4) but less likely to forage (Fig. 6) as distance to unburned stands increased. 

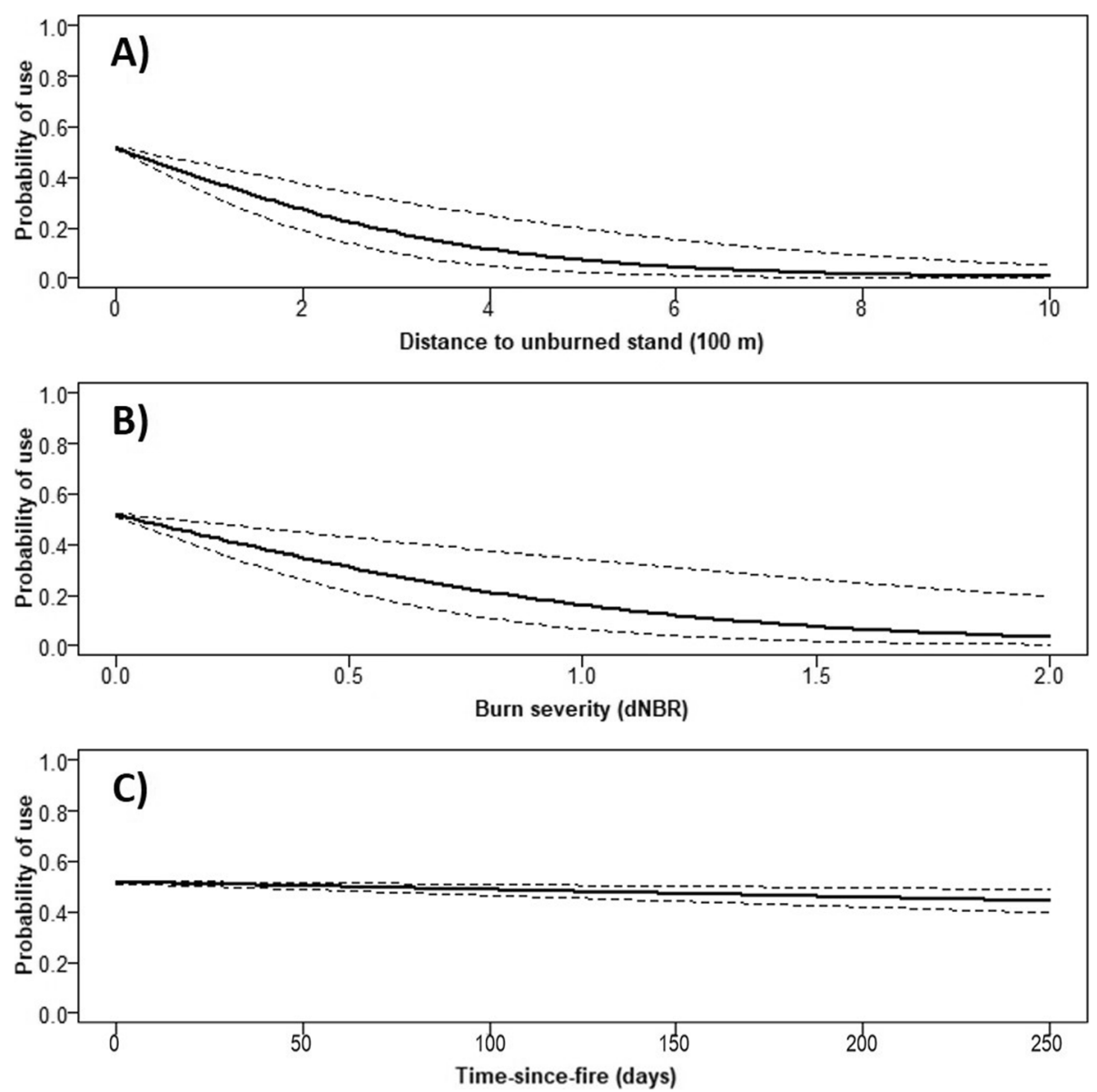

Fig. 2 Predicted probability of use (solid line) \pm standard error (dotted line) of burned areas ( $\leq 250$ days post burn) by female eastern wild turkeys (Meleagris gallopavo silvestris) as a function of (A) distance to unburned stand, (B) burn severity, and (C) time-since-fire. Data were collected from GPS-tagged wild turkeys at Silver Lake Wildlife Management Area in Georgia, Webb Center Complex in South Carolina, and Kisatchie National Forest in Louisiana, USA, between 1 March and 31 July, from 2014 to 2017

For example, probability of walking increased 50\% but probability of foraging decreased by approximately $40 \%$ as distance to unburned stand increased from 0 to $500 \mathrm{~m}$. Distance to unburned stand did not affect probability of loafing in burned areas. Burn severity affected the probability of all three behavioral states; turkeys were less likely to forage (Fig. 6) and loaf (Fig. 5), but more likely to walk (Fig. 4) in areas as burn severity increased. For example, probability of foraging decreased to almost zero when dNBR values approached 1.5, whereas probability of walking increased nearly $140 \%$ as burn severity increased from 0.0 to 2.0. Lastly, turkeys were more likely to forage (Fig. 6), but less likely to walk (Fig. 4) as burn heterogeneity increased. Probability of foraging increased by approximately $40 \%$ as burn heterogeneity increased from 0.0 to 2.0 , while probability of walking decreased by $20 \%$. Burn heterogeneity did not affect the probability of loafing.

\section{Discussion}

Prescribed fire is applied in southeastern USA pinedominated ecosystems to mimic historic fire regimes and promote early successional understory vegetation favored by disturbance-dependent species (e.g., redcockaded woodpecker [Picoides borealis Vieillot, 1809], gopher tortoise [Gopherus polyphemus Daudin, 1802], and northern bobwhite [Colinus virginianus, Linnaeus, 1758]). Animal populations residing in these ecosystems are linked to frequent fires (e.g., 2- to 5-year burn rotations) and have adopted behaviors to exploit shifts in resources caused by disturbance (Hutto et al. 2008; Fontaine and Kennedy 2012). Although only $11.6 \%$ to $25.7 \%$ of our study areas were burned annually, $79 \%$ of turkeys had burned areas available to them and $87 \%$ used recently burned stands. Furthermore, turkeys with burned areas in their range rapidly responded to prescribed fire, with $73 \%$ using burned areas within 30 days post burn. Turkeys were also more likely to forage inside 


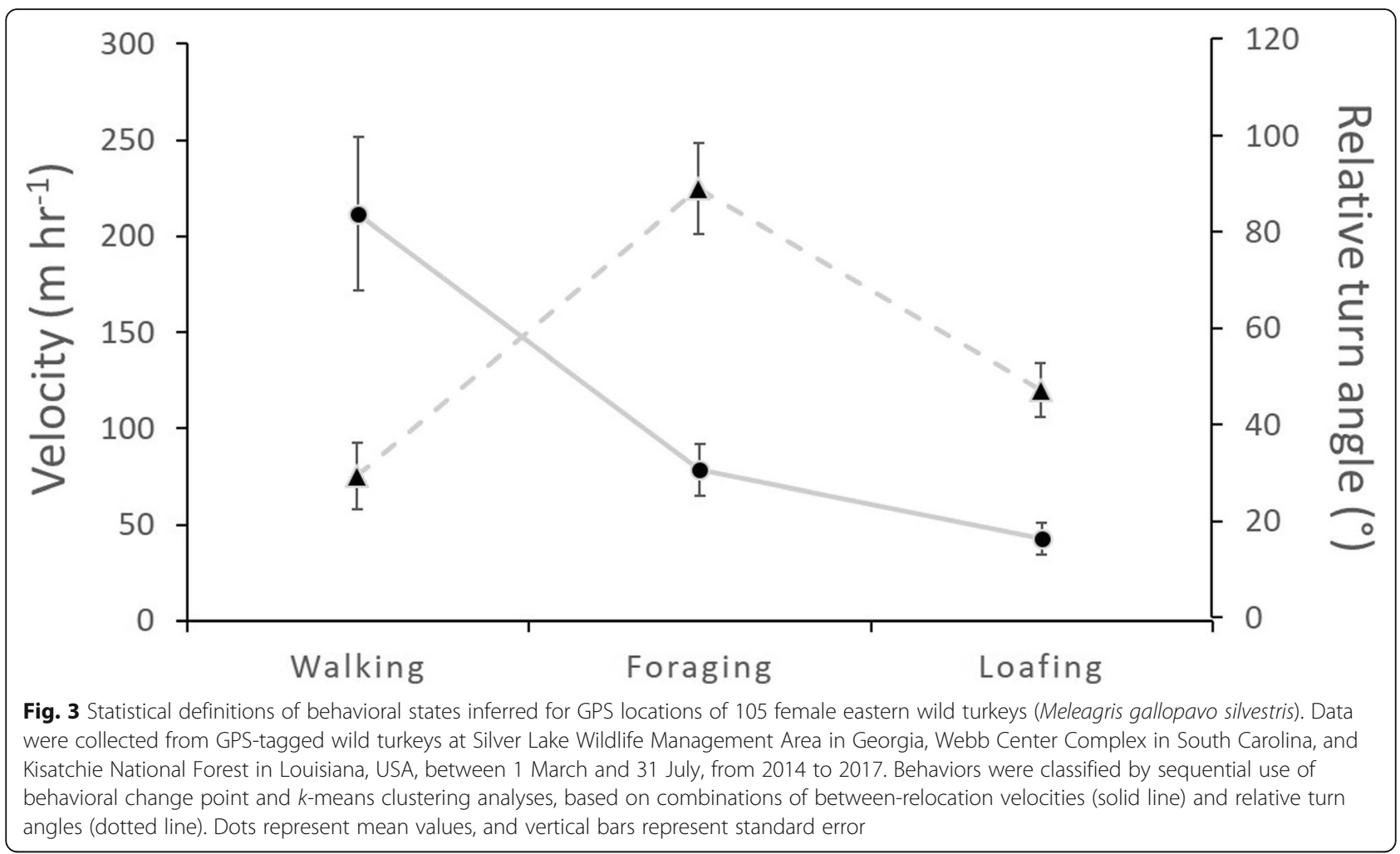

burned stands, suggesting that turkeys responded to these areas because of quality foraging opportunities created by prescribed fires. Wild turkeys forage on a wide diversity of prey items, but foraging activities are closely tied to availability of succulent green vegetation, various seed-producing plants, and insects from early spring until late summer (Hurst 1992), which coincided with our monitoring and analyses. Prescribed fire immediately immobilizes and exposes insects to predation, while creating vegetation conditions attractive to recolonizing insects (Swengel 2001), resulting in higher densities of invertebrates in burned areas than unburned areas (Hurst 1972; Brennan et al. 2000). Our results suggest that turkeys in pyric landscapes are well adapted to fire disturbances and rely on burned areas during their life cycle (Yeldell et al. 2017b; Wood et al. 2018). We noted that turkeys use burned areas quickly post fire. Previous authors have reported selection for areas $\leq 2 \mathrm{yr}$ post burn during all phases of the reproductive period (i.e., laying, nesting, brooding; Martin et al. 2012; Kilburg et al. 2014; Little et al. 2016; Yeldell et al. 2017a; Yeldell et al. 2017b; Wood et al. 2018).

Recent evidence suggests that turkey use of burned stands peaks around 141 days post fire and declines thereafter (Yeldell et al. 2017c). Similarly, we noted that turkeys were less likely to use burned areas as time-since-fire increased. As time-since-fire increases, vegetation communities become similar in structure to those in areas not recently burned. Specifically, herbaceous communities decline (Haywood 2009, 2010), as does prevalence of bare ground (Jones et al. 2013), and midstory and canopy vegetation increase (Wiggers et al. 2013). Collectively, as time progresses post burn, burned areas likely become similar in habitat suitability for turkeys (Provencher et al. 2001; Beckage et al. 2009), as vegetation and insect communities more closely mimic surrounding unburned areas. Turkeys tended to loaf in burned areas as time-since-fire increased, which we suspect is a function of vegetation recovery post burn. Ideal loafing vegetation should provide cover and thermal refuge, while allowing an unobstructed visual field for predator detection (Dickson 1992). Loafing conditions decline in subsequent growing seasons as hardwood and shrub vegetation sprouts (Glitzenstein et al. 2012), creating thicker understory conditions, which hinders turkey movement and obstructs their visual field.

The size and shape of burned stands affects both spatial distribution and juxtaposition of resources across a landscape (Pickett et al. 1989; McKenzie et al. 2011; Parkins et al. 2018). The proximity of resources affects behavior, and in turn drives demographic outcomes (Ries et al. 2004; Wellendorf and 

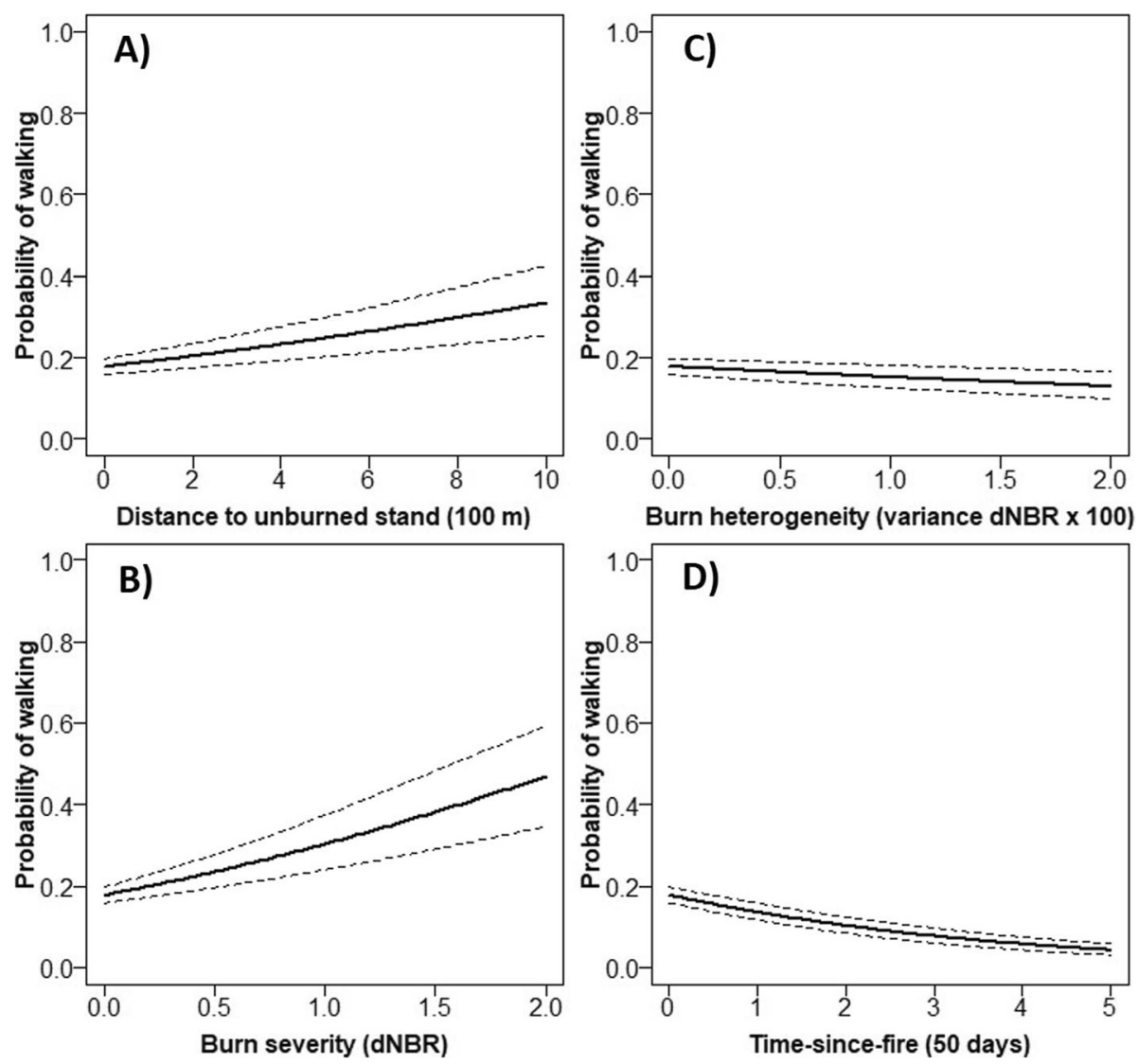

Fig. 4 Predicted probability of female eastern wild turkeys (Meleagris gallopavo silvestris) engaging in walking behavior (solid line) \pm standard error (dotted line) while using burned areas ( $\leq 250$ days post burn) as a function of (A) distance to unburned stands, (B) burn severity, (C) burn heterogeneity, (D) and time-since-fire. Data were collected from GPS-tagged wild turkeys at Silver Lake Wildlife Management Area in Georgia, Webb Center Complex in South Carolina, and Kisatchie National Forest in Louisiana, USA, between 1 March and 31 July, from 2014 to 2017

Palmer 2006; Hovick et al. 2015). Our results demonstrate that the scale of prescribed fire affects turkeys' use within burned stands. The probability of turkeys using burned areas declined as distance to adjacent unburned stands increased, decreasing by $50 \%$ between 0 to $250 \mathrm{~m}$, and declining to almost zero use after $600 \mathrm{~m}$. Likewise, turkeys were less likely to forage and more likely to walk when farther from unburned stands, suggesting that proximity of burned and unburned areas creates favorable foraging conditions. Presumably, turkeys used areas closer to unburned stands because the denser vegetation provided escape or thermal cover, as previously noted for northern bobwhite (Kassinis and Guthery 1996) and Himalayan snowcock (Tetraogallus himalayensis G.R. Gray 1843; Bland and Temple 1990). Alternatively, vegetation in surrounding unburned stands would not only be structurally different, but also support prey resources (e.g., insects) different from those in recently burned areas because of the availability of refugia for insects when fires were initially applied
(Knight and Holt 2005). Insect abundance is also typically greater at the edges of burned areas compared to interior areas because insects recolonize these areas more quickly (Porter and Redak 1996; Knight and Holt 2005; Mutz et al. 2017). Nonetheless, farther distances away from areas not burned resulted in turkeys walking through these areas, suggesting that these areas are less suitable in the year prescribed fire is applied. Prescribed fire applied to create interior areas $<250 \mathrm{~m}$ from adjacent unburned stands, or to stands shaped to maximize edge-to-area ratios likely create more suitable conditions for turkeys.

Burn severity affects patterns in avian use, behavior, and biodiversity (Artman et al. 2005; Klaus et al. 2010; Lindenmayer et al. 2014; Rose et al. 2016). The degree of burn severity is a proximate measure of vegetation removal, with severity ranging from minimal damage to understory vegetation and removal of thatch to complete mortality of midstory and canopy vegetation (Platt and Connell 2003; Thaxton and Platt 2006; Gagnon et al. 2015). More severe burns are also 


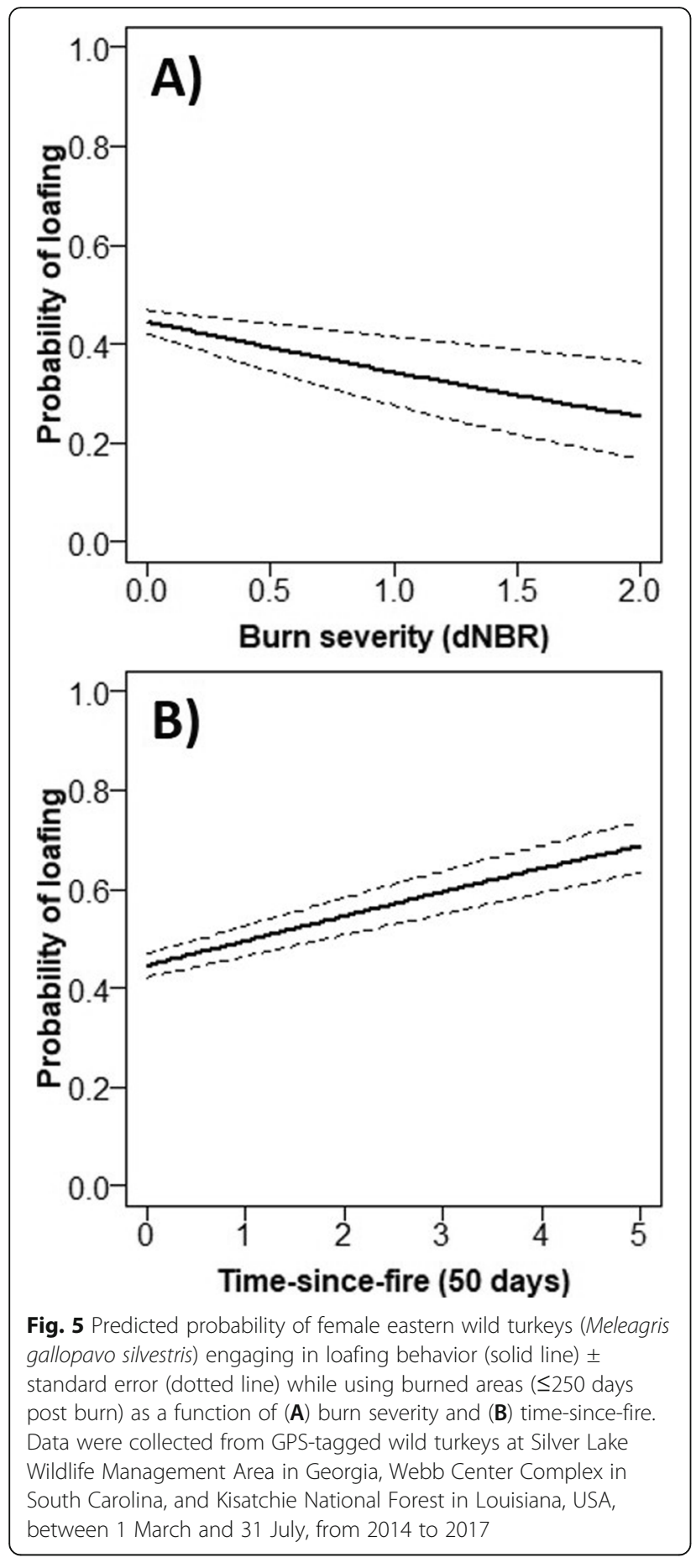

associated with delayed plant regrowth in the understory (Lavoie et al. 2010). Thus, lower burn severities are associated with increased herbaceous biomass, structural heterogeneity, and vegetation diversity (Brockway and Lewis 1997; Kirkman et al. 2004; Grady and Hoffmann 2012). Beyond reductions in herbaceous vegetation, higher burn severities are associated with reductions in invertebrate density and diversity (New 2014). Oetgen et al. (2015) noted that turkeys avoided more severely burned areas created after a natural wildfire in Texas, USA, presumably because of drastic alterations to vegetation communities. Similarly, our results suggest that turkeys are less likely to use areas within stands that are more severely burned after prescribed fire. When using burned stands, turkeys were less likely to forage and loaf, and more likely to walk, in more severely burned areas. We offer that turkeys avoided foraging and loafing in more severely burned areas simply because of reductions in habitat quality within these areas. Notably, increases in burn severity are often associated with the buildup of fuel loads resulting from less-frequent fire return intervals (Albini 1976; Thaxton and Platt 2006; Gagnon et al. 2015). Hence, managers should apply prescribed fire frequently enough to promote low-severity burns, which will vary across landscapes depending on fuel loads, fire history, ignition sources, and weather, among other things (Ryan et al. 2013; Gagnon et al. 2015; Platt et al. 2016; Wragg et al. 2018).

Turkeys in our study had different percentages of their available landscape burned annually. We recognize that the amount of area burned within an individual's range may affect its response. On one hand, individuals residing in landscapes where less areas are burned may not have responded when fire was sparsely distributed; conversely, turkeys may be more likely to exploit burned areas if recently burned forested stands provide important resources not found elsewhere. It is also possible that different reproductive stages (e.g., pre-nesting, brood-rearing) could affect the relative importance of these burned areas to female turkeys. For example, burned stands may provide decreased visual obstruction, improved mobility, and increased availability of insects for poults (Yeldell et al. 2017b). Future research should focus on the response of turkeys to burned areas based on the availability of these areas within their range, and the reproductive stage that the female is in.

Behavior is the primary mechanism underlying mortality risk and reproductive success in dynamic landscapes (Heinen et al. 2013). We linked fire characteristics measured via satellite imagery to behavioral responses of turkeys that were located using GPS data. Because BCPA requires no a priori knowledge about the movements and behaviors of animals, we have no way of verifying the behavioral states that we derived from our analyses. It is possible that similarities in velocity between loafing and foraging behaviors affected our sensitivity to detect shifts between these two behaviors. Similarly, we 

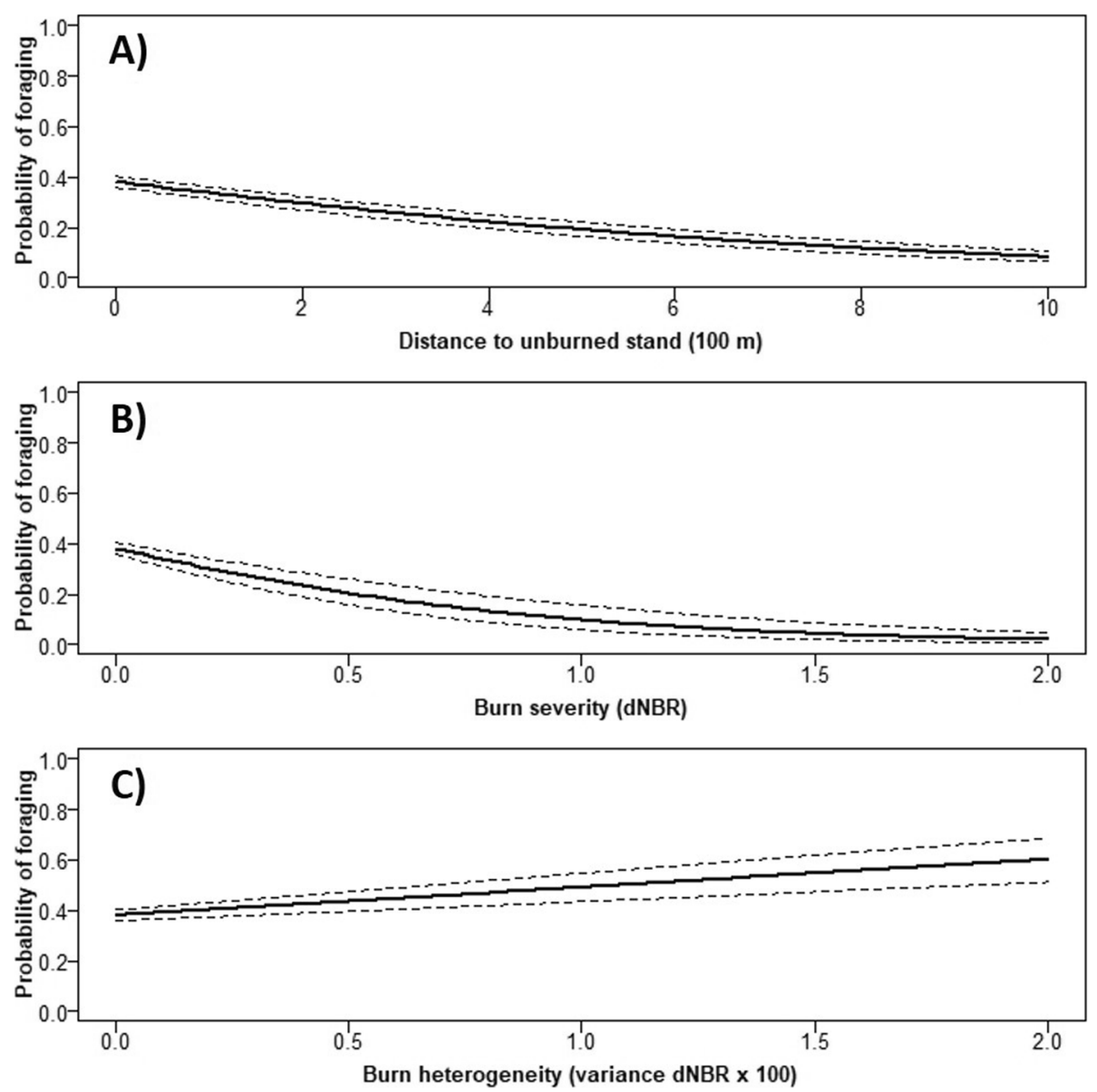

Fig. 6 Predicted probability of female eastern wild turkeys (Meleagris gallopavo silvestris) engaging in foraging behavior (solid line) \pm standard error (dotted line) while using burned areas ( $\leq 250$ days postburn) as a function of (A) distance to unburned stands, (B) burn severity, and (C) burn heterogeneity. Data were collected from GPS-tagged wild turkeys at Silver Lake Wildlife Management Area in Georgia, Webb Center Complex in South Carolina, and Kisatchie National Forest in Louisiana, USA, between 1 March and 31 July, from 2014 to 2017

recognize that turkey foraging and loafing behaviors are not mutually exclusive. For example, turkeys will forage on nearby herbaceous plants and insects while resting (Healy 1992). Nonetheless, our findings suggest that fire characteristics affect how turkeys respond to prescribed fire events in areas where fire is frequently applied, and that these same characteristics can affect habitat suitability. We noted that more severe burns created less suitable foraging and loafing habitats for turkeys. Likewise, our findings demonstrated that areas farther into the interior of burned stands are unlikely to be used by turkeys during the same growing season in which the fire occurred.

\section{Conclusions}

Accurately discerning behaviors at a fine scale and understanding environmental factors mediating those behaviors is critical for informing management decisions (Cooke 2008). In particular, identifying how disturbance and characteristics associated with disturbance affect animal foraging or resting behavior is critical for conservation efforts, as these behaviors are directly linked to parameters affecting individual fitness (Wong and Candolin 2015). Collectively, our findings suggest that how prescribed fire is applied to landscapes has important implications to useable space (Guthery 1997) for some species, particularly those residing in frequently burned landscapes. Hence, managers should design prescribed fire regimes with the recognition that sizes of burned stands and fire severity, along with determinants of fire severity (e.g., fuel loads, return intervals, timing), are important influences on animal behavior in frequentfire-managed landscapes. Future research should elucidate the optimal spatial arrangement of burn patches in conjunction with estimates of individual relative fitness. 


\section{Supplementary information}

Supplementary information accompanies this paper at https://doi.org/10. 1186/s42408-019-0058-4.

Additional file 1. Distribution and number of female eastern wild turkeys (Meleagris gallopavo silvestris) that used recently burned areas (i.e., areas $\leq 250$ days post burn) at three study sites within three states in southeastern United States. Data were collected from GPS-tagged wild turkeys at Silver Lake Wildlife Management Area in Georgia, Webb Center Complex in South Carolina, and Kisatchie National Forest in Louisiana, USA, between 1 March and 31 July, from 2014 to 2017. We used Global Positioning System data associated with each wild turkey to investigate effects of time-since-fire, burn severity, burn heterogeneity, and distance to unburned stands on turkey behavior.

Additional file 2. Example of behavioral states assigned to an individual's GPS track inside and outside a burned area. Data were collected from GPS-tagged wild turkeys at Silver Lake Wildlife Management Area in Georgia (SLWMA), USA, between 1 March and 31 July, from 2014 to 2017. To assign behavioral states, we used behavioral change point and $k$-means clustering analyses. All locations for an individual's track were assigned a behavioral state based on velocity and relative turn angles, and then locations inside burned areas and their associated values of burn severity (dNBR), burn heterogeneity (variance dNBR), distance to unburned stand, and time-sincefire were extracted for analyses. Results of our behavioral change point analysis determined that turkeys engaged in three behavioral states, for which we assigned $1=$ walking, $2=$ foraging, and $3=$ loafing. Black dots with brown edges are GPS relocations of a single adult female wild turkey located on SLWMA (entire site shown on bottom right of figure).

\section{Acknowledgements}

We thank N. Yeldell, P. Wightman, and J. Wood for their efforts in collecting field data. This material is based partially on work supported by the National Institute of Food and Agriculture, US Department of Agriculture, McIntire Stennis project under No. 1005302.

\section{Authors' contributions}

BSC, BAC, and MJC conceived, designed, and performed the data analysis and wrote the manuscript. TJP contributed to the conceptual ideas, experimental design, data analysis, and writing. All authors read and approved the final manuscript.

\section{Funding}

This project was funded by Texas Parks and Wildlife Department, the Georgia Department of Natural Resources-Wildlife Resources Division, the Louisiana Department of Wildlife and Fisheries, the Louisiana State University Agricultural Center, the South Carolina Department of Natural Resources, and the Warnell School of Forestry and Natural Resources at the University of Georgia.

\section{Availability of data and materials}

The datasets generated or analyzed during the current study are not publicly available because they are being used in ongoing research and analyses but are available from the corresponding author on reasonable request.

\section{Ethics approval and consent to participate}

All turkey capture, handling, and marking procedures were approved by the Institutional Animal Care and Use Committee at the University of Georgia (Protocol \#A2014 06-008-Y1-A0 and A3437-01) and the Louisiana State University Agricultural Center (Protocol \#A2014-013 and A2015-07).

\section{Consent for publication}

Not applicable.

\section{Competing interests}

The authors declare that they have no competing interests.

\section{Author details}

'Department of Biology, Tennessee Technological University, 1100 N Dixie Avenue, Cookeville, TN 38505, USA. ${ }^{2}$ Warnell School of Forestry and Natural Resources, University of Georgia, 180 E Green Street, Athens, GA 30602, USA.
${ }^{3}$ School of Renewable Natural Resources, Louisiana State University Agricultural Center, 341 Renewable Natural Resources Building, Baton Rouge LA 70803, USA.

Received: 28 May 2019 Accepted: 25 October 2019

Published online: 04 December 2019

\section{References}

Albini, F.A. 1976. Estimating wildfire behavior and effects. USDA Forest Service General Technical Report INT-30. Ogden: USDA Forest Service, Intermountain Forest and Range Experiment Station.

Andersson, M., J. Wallander, and D. Isaksson. 2009. Predator perches: a visual search perspective. Functional Ecology 23: 373-379 https://doi.org/10.1111/j. 1365-2435.2008.01512.x

Artman, V.L., T.F. Hutchinson, and J.D. Brawn. 2005. Fire ecology and bird populations in eastern deciduous forests. Studies in Avian Biology 30: 127-138.

Baker, W.L. 1993. Spatially heterogeneous multi-scale response of landscapes to fire suppression. Oikos 66: 66-71 https://doi.org/10.2307/3545196.

Bates, D., M. Maechler, B. Bolker, and S. Walker. 2015. Fitting linear mixed-effects models using Ime4. Journal of Statistical Software 67: 1-48 https://doi.org/10. 18637/jss.v067.i01.

Beckage, B., W.J. Platt, and L.J. Gross. 2009. Vegetation, fire, and feedbacks: a disturbance-mediated model of savannas. American Naturalist 174: 805-818 https://doi.org/10.1086/648458.

Bissonette, J.A. 2017. Avoiding the scale sampling problem: a consilient solution. Journal of Wildlife Management 81 (2): 192-205 https://doi.org/10.1002/jwmg. 21187.

Bland, J.D., and S.A. Temple. 1990. Effects of predation-risk on habitat use by Himalayan snowcocks. Oecologia 82 (2): 187-191 https://doi.org/10.1007/ BF00323534.

Brennan, L.A., J.M. Lee, E.L. Staller, S.D. Wellendorf, and R.S. Fuller. 2000. Effects of seasonal fire applications on northern bobwhite brood habitat and hunting success. In Quail N: proceedings of the National Quail Symposium, ed. L.A. Brennan, W.E. Palmer, L.W. Burger, and T.L. Pruden, 66-69. Tallahassee: Tall Timbers Research Station.

Briani, D.C., A.R.T. Palma, E.M. Vieira, and R.P.B. Henriques. 2004. Post-fire succession of small mammals in the Cerrado of central Brazil. Biodiversity and Conservation 13: 1023-1037 https://doi.org/10.1023/B:BIOC.0000014467.27138.0b.

Brockway, D.G., and C.E. Lewis. 1997. Long-term effects of dormant-season prescribed fire on plant community diversity, structure and productivity in a longleaf pine wiregrass ecosystem. Forest Ecology and Management 96: 167183 https://doi.org/10.1016/S0378-1127(96)03939-4

Burk, J.D., D.R. Smith, G.A. Hurst, B.D. Leopold, and M.A. Melchiors. 1990. Wild turkey use of loblolly pine plantations for nesting and brood rearing. Proceedings of the Southeastern Association of Fish and Wildlife Agencies 44: 163-170.

Byrne, M.E., J.D. Guthrie, J. Hardin, B.A. Collier, and M.J. Chamberlain. 2014. Evaluating wild turkey movement ecology: an example of using first-passage time analysis. Wildlife Society Bulletin 38: 407-413 https://doi.org/10.1002/wsb.404.

Campo, J.J., W.G. Swank, and C.R. Hopkins. 1989. Brood habitat use by eastern wild turkeys in eastern Texas. Journal of Wildlife Management 53: 479-482 https://doi.org/10.2307/3801153.

Candolin, U., and B.B.M. Wong. 2012. Behavioural responses to a changing world: mechanisms and consequences. Oxford: Oxford University Press https://doi. org/10.1093/acprof:osobl/9780199602568.001.0001.

Cohen, B.S., T.J. Prebyl, B.A. Collier, and M.J. Chamberlain. 2018. Home range estimator method and GPS fix schedule affect selection inferences for wild turkeys. Wildlife Society Bulletin 42: 150-159 https://doi.org/10.1002/wsb.845.

Cooke, S.J. 2008. Biotelemetry and biologging in endangered species research and animal conservation: relevance to regional, national, and IUCN Red List threat assessments. Endangered Species Research 4: 165-185 https://doi.org/ 10.3354/esr00063.

Core Team, R. 2017. R: a language and environment for statistical computing. Vienna: R Foundation for Statistical Computing

Dickson, J.G. 1992. The wild turkey: biology and management. Mechanicsburg: Stackpole Books.

Dormann, C.F., J. Elith, S. Bacher, C. Buchmann, G. Carl, G. Carré, J.R.G. Marquéz, B. Gruber, B. Lafourcade, P.J. Leitão, T. Münkemüller, C. McClean, P.E. Osborne, B. Reineking, B. Schröder, A.K. Skidmore, D. Zurell, and S. Lautenbach. 2013. Collinearity: a review of methods to deal with it and a simulation study evaluating their performance. Ecography 36: 27-46 https://doi.org/10.1111/j. 1600-0587.2012.07348.x. 
Dunning, J.B., B.J. Danielson, and H.R. Pulliam. 1992. Ecological processes that affect populations in complex landscapes. Oikos 65: 169-175 https://doi.org/ $10.2307 / 3544901$

Ellair, D.P., and W.J. Platt. 2013. Fuel composition influences fire characteristics and understory hardwoods in pine savannas. Journal of Ecology 101: 192-201 https://doi.org/10.1111/1365-2745.12008

Elliot, K.J., J.M. Vose, and R.L. Hendrick. 2009. Long-term effects of high intensity prescribed fire on vegetation dynamics in the Wine Spring Creek watershed, western North Carolina, USA. Fire Ecology 5: 66-85 https://doi.org/10.4996/ fireecology.0502066.

Ernst, S., L. Lymburner, and J.S. Sixsmith. 2018. Implications of pixel quality flags on observation density of a continental Landsat archive. Remote Sensing 2018 10 (10): 1570 https://doi.org/10.3390/rs10101570.

Exum, J.H., J.A. McGlincy, D.W. Speake, J.L. Buckner, and F M. Stanley. 1987. Ecology of the eastern wild turkey in an intensively managed pine forest in southern Alabama. Tall Timbers Research Station Bulletin 23:1-70.

Fauchald, P., and T. Tveraa. 2003. Using first-passage time in the analysis of arearestricted search and habitat selection. Ecology 84: 282-288 https://doi.org/ 10.1890/0012-9658(2003)084[0282:UFPTIT]2.0.CO;2.

Fontaine, J.B., and P.L. Kennedy. 2012. Meta-analysis of avian and small-mammal response to fire severity and fire surrogate treatments in US fire-prone forests. Ecological Applications 22: 1547-1561 https://doi.org/10.1890/12-0009.1.

Gagnon, P.R., H.A. Passmore, M. Slocum, J.A. Myers, K.E. Harms, W.J. Platt, and C.E. T. Paine. 2015. Fuels and fires influence vegetation via above- and belowground pathways in a high-diversity plant community. Journal of Ecology 103: 1009-1019 https://doi.org/10.1111/1365-2745.12421.

Glitzenstein, J.S., D.R. Streng, R.E. Masters, K.M. Robertson, and S.M. Hermann. 2012. Fire frequency effects on vegetation in north Florida pinelands: another look at the long term Stoddard Fire research plots at Tall Timbers Research Station. Forest Ecology and Management 264: 197-209 https://doi. org/10.1016/j.foreco.2011.10.014

Gorelick, N., M. Hancher, M. Dixon, S. Ilyushchenko, D. Thau, and R. Moore. 2017. Google Earth Engine: planetary-scale geospatial analysis for everyone. Remote Sensing of Environment 202: 18-27 https://doi.org/10.1016/j.rse.2017.06.031.

Grady, J., and W.A. Hoffmann. 2012. Caught in a fire trap: recurring fire creates stable size equilibria in woody resprouters. Ecology 93: 2052-2060 https://doi. org/10.1890/12-0354.1.

Gurarie, E. 2014. bcpa: behavioral change point analysis of animal movement. https://CRAN.R-project.org/package=bcpa. Accessed 1 July 2017

Gurarie, E., R.D. Andrews, and K.L. Laidre. 2009. A novel method for identifying behavioural changes in animal movement data. Ecology Letters 12: 395-408 https://doi.org/10.1111/j.1461-0248.2009.01293.x.

Gurarie, E., C. Bracis, M. Delgado, T.D. Meckley, I. Kojola, and C.M. Wagner. 2016. What is the animal doing? Tools for exploring behavioural structure in animal movements. Journal of Animal Ecology 85: 69-84 https://doi.org/10. 1111/1365-2656.12379.

Guthery, F.S. 1997. A philosophy of habitat management for northern bobwhites. Journal of Wildlife Management 61: 291-301 https://doi.org/10.2307/3802584.

Guthrie, J.D., M.E. Byrne, J.B. Hardin, C.O. Kochanny, K.L. Skow, R.T. Snelgrove, M.J. Butler, M.J. Peterson, M.J. Chamberlain, and B.A. Collier. 2011. Evaluation of a GPS backpack transmitter for wild turkey research. Journal of Wildlife Management 75: 539-547 https://doi.org/10.1002/jwmg.137.

Harrod, J.C., M.E. Harmon, and P.S. White. 2000. Post-fire succession and 20th century reduction in fire frequency on xeric southern Appalachian sites. Journal of Vegetation Science 11: 465-472 https://doi.org/10.2307/3246576.

Hartigan, J.A., and M.A. Wong. 1979. Algorithm AS 136: a k-means clustering algorithm. Applied Statistics 28: 100-108 https://doi.org/10.2307/2346830.

Hayes, J.J., and S.M. Robeson. 2011. Relationships between fire severity and postfire landscape pattern following a large mixed-severity fire in the Valle Vidal, New Mexico, USA. Forest Ecology and Management 261: 1392-1400 https:// doi.org/10.1016/j.foreco.2011.01.023.

Haywood, J.D. 2009. Eight years of seasonal burning and herbicidal brush control influence sapling longleaf pine growth, understory vegetation, and the outcome of an ensuing wildfire. Forest Ecology and Management 258: 295 305 https://doi.org/10.1016/j.foreco.2009.04.016.

Haywood, J.D. 2010. Effects of prescribed fire on vegetation and fuel loads in longleaf pine stands in the bluestem range. Proceedings of the 14th Biennial Southern Silvicultural Research Conference 14: 213-217.

Haywood, J.D. 2012. Frequency and season of prescribed fire affect understory plant communities in longleaf pine stands. Proceedings of the 16th Biennial Southern Silvicultural Research Conference 16: 137-143.
Healy, W.M. 1992. Behavior. In The wild turkey: biology and management, ed. J.G. Dickson, 46-65. Mechanicsburg: Stackpole Books.

Heinen, J.L., M.W. Coco, M.S. Marccuard, D.N. White, M.N. Peterson, R.A. Martin, and R.B. Langerhans. 2013. Environmental drivers of demographics, habitat use, and behavior during a post-Pleistocene radiation of Bahamas mosquitofish (Gambusia hubbsi). Evolutionary Ecology 27: 971-991 https://doi. org/10.1007/s10682-012-9627-6.

Hennig, C. 2018. fpc: flexible procedures for clustering. https://CRAN.R-project. org/package=fpc. Accessed 1 Feb 2018.

Hovick, T.J., B.W. Allred, R.D. Elmore, S.D. Fuhlendorf, R.G. Hamilton, and A. Breland. 2015. Dynamic disturbance processes create dynamic lek site selection in a prairie grouse. PLOS ONE 10: e0137882 https://doi.org/10.1371/ journal.pone.0137882.

Hurst, G.A. 1972. Insects and bobwhite quail brood habitat management. In Proceedings of the First National Bobwhite Quail Symposium, ed. J.A. Morisson, J.C. Lewis, W.D. Klimstra, J.W. Rosene, and J.A. Stanford, 65-82. Stillwater: Oklahoma State University.

Hurst, G.A. 1992. Foods and feeding. In The wild turkey: biology and management, ed. J.G. Dickson, 66-83. Mechanicsburg: Stackpole Books.

Hurteau, S.R., W.M. Block, and B.G. Dickson. 2008. Fuel-reduction treatment effects on avian community structure and diversity. Journal of Wildlife Management 72: 1168-1174 https://doi.org/10.2193/2007-351.

Hutto, R.L., C.J. Conway, V.A. Saab, and J.R. Walters. 2008. What constitutes a natural fire regime? Insight from the ecology and distribution of coniferous forest birds in North America. Fire Ecology 4 (2): 115-132 https://doi.org/10. 4996/fireecology.0402115.

Jones, C.D., J.A. Cox, E. Toriani-Moura, and R.J. Cooper. 2013. Nest-site characteristics of Bachman's sparrows and their relationship to plant succession following prescribed burns. Wilson Journal of Ornithology 125: 293-300 https://doi.org/10.1676/12-119.1.

Kassinis, N.I., and F.S. Guthery. 1996. Flight behavior of northern bobwhites. Journal of Wildlife Management 60: 581-585 https://doi.org/10.2307/3802075.

Key, C.H., and N.C. Benson. 2006. Landscape assessment (la): sampling and analysis methods. USDA Forest Service General Technical Report RMRS-GTR164-CD. Ogden: USDA Forest Service, Rocky Mountain Research Station.

Kilburg, E.L., C.E. Moorman, C.S. Deperno, D. Cobb, and C.A. Harper. 2014. Wild turkey prenesting-resource selection in a landscape managed with prescribed fire. Southeastern Naturalist 14: 137-146 https://doi.org/10.1656/ 058.014.0114

Kirkman, L., P. Goebel, B. Palik, and L. West. 2004. Predicting plant species diversity in a longleaf pine landscape. Écoscience 11: 80-93 https://doi.org/10 1080/11956860.2004.11682812.

Klaus, N.A., S.A. Rush, T.S. Keyes, J. Petrick, and R.J. Cooper. 2010. Short term effects of fire on breeding birds in southern Appalachian upland forests. Wilson Journal of Ornithology 122: 518-531 https://doi.org/10.1676/09-105.1.

Knight, T.M., and R.D. Holt. 2005. Fire generates spatial gradients in herbivory: an example from a Florida sandhill ecosystem. Ecology 86: 587-593 https://doi. org/10.1890/04-1069.

Krzanowski, W.J., and Y. Lai. 1988. A criterion for determining the number of groups in a data set using sum-of-squares clustering. Biometrics 44: 23-34 https://doi.org/10.2307/2531893.

Kush, J.S., R.S. Meldahl, and W.D. Boyer. 2000. Understory plant community response to season of burn in natural longleaf pine forests. Tall Timbers Fire Ecology Conference Proceedings 21: 33-39.

Lai, S., J. Bêty, and D. Berteaux. 2015. Spatio-temporal hotspots of satellite tracked arctic foxes reveal a large detection range in a mammalian predator. Movement Ecology 3: 37 https://doi.org/10.1186/s40462-015-0065-2.

Lavoie, M., G. Starr, M.C. Mack, T.A. Martin, and H.L. Gholtz. 2010. Effects of a prescribed fire on understory vegetation, carbon pools, and soil nutrients in a longleaf pine-slash pine forest in Florida. Natural Areas Journal 30: 82-94 https://doi.org/10.3375/043.030.0109.

Lindenmayer, D.B., W. Blanchard, L. McBurney, D. Blair, S.C. Banks, D.A. Driscoll, A. L. Smith, and A.M. Gill. 2014. Complex responses of birds to landscape-level fire extent, fire severity, and environmental drivers. Diversity and Distributions 20: 467-477 https://doi.org/10.1111/ddi.12172.

Little, A.R., M.J. Chamberlain, L.M. Conner, and R.J. Warren. 2016. Habitat selection of wild turkeys in burned longleaf pine savannas. Journal of Wildlife Management 80: 1280-1289 https://doi.org/10.1002/jwmg.21114.

Madden, E.M., A.J. Hansen, and R.K. Murphy. 1999. Influence of prescribed fire history on habitat and abundance of passerine birds in northern mixed-grass prairie. Canadian Field Naturalist 113: 627-640. 
Maechler, M., P. Rousseeuw, A. Struyf, M. Hubert, and K. Hornik. 2017. cluster: cluster analysis basics and extensions. https://cran.r-project.org/web/ packages/cluster/cluster.pdf. Accessed 15 Dec 2017.

Martin, J.A., W.E. Palmer, S.M. Juhan Jr., and J.P. Carroll. 2012. Wild turkey habitat use in frequently-burned pine savanna. Forest Ecology and Management 285: 179-186 https://doi.org/10.1016/j.foreco.2012.07.051.

Masek, J.G., E.F. Vermote, N.E. Saleous, R. Wolfe, F.G. Hall, K.F. Huemmrich, F. Gao, J. Kutler, and L. Teng-Kui. 2006. A Landsat surface reflectance dataset for North America, 1990-2000. IEEE Geoscience and Remote Sensing Letters 3 (1): 68-72 https://doi.org/10.1109/LGRS.2005.857030.

McKenzie, D., C. Miller, and D.A. Falk. 2011. The landscape ecology of fire. New York: Springer https://doi.org/10.1007/978-94-007-0301-8.

Miller, J.D., and A.E. Thode. 2007. Quantifying burn severity in a heterogeneous landscape with a relative version of the delta Normalized Burn Ratio (dNBR). Remote Sensing of Environment 109 (1): 66-80 https:/doi.org/10.1016/j.rse.2006.12.006.

Mutz, J., N. Underwood, and B.D. Inouye. 2017. Time since disturbance affects colonization dynamics in a metapopulation. Journal of Animal Ecology 86: 1065-1073 https://doi.org/10.1111/1365-2656.12689.

New, T.R. 2014. Insects, fire and conservation. Switzerland: Springer International Publishing.

Northrup, J.M., M.B. Hooten, C.R. Anderson Jr., and C. Wittemyer. 2013. Practical guidance on characterizing availability in resource selection functions under a use-availability design. Ecology 94: 1456-1463 https://doi.org/10.1890/12-1688.1.

Oetgen, J., A. Engeling, A. Dube, K.L. Skow, M.J. Chamberlain, and B.A. Collier. 2015. Evaluating Rio Grande wild turkey movements post catastrophic wildfire using two selection analysis approaches. Proceedings of the National Wild Turkey Symposium 11: 127-142.

Palmer, W.E., and G.A. Hurst. 1998. Prescribed burning effects on wild turkey hens during preincubation. Tall Timbers Fire Ecology Proceedings 20: 102-106.

Parkins, K., A. York, and J. Di Stefano. 2018. Edge effects in fire-prone landscapes: ecological importance and implications for fauna. Ecology and Evolution 8: 5937-5948 https://doi.org/10.1002/ece3.4076.

Penman, T., R. Kavanagh, D. Binns, and D. Melick. 2007. Patchiness of prescribed burns in dry sclerophyll eucalypt forests in south-eastern Australia. Forest Ecology and Management 252: 24-32 https://doi.org/10.1016/j.foreco.2007.06.004.

Pickett, S.T.A., J. Kolasa, J. Armesto, and S.L. Collins. 1989. The ecological concept of disturbance and its expression at various hierarchical levels. Oikos 54: 129 136 https://doi.org/10.2307/3565258.

Picotte, J.J., and K.M. Robertson. 2011. Validation of remote sensing of burn severity in south-eastern US ecosystems. International Journal of Wildland Fire 20: 453-464 https://doi.org/10.1071/WF10013.

Platt, W.J., and J.H. Connell. 2003. Natural disturbances and directional replacement of species. Ecological Monographs 73: 507-522 https://doi.org/ 10.1890/01-0552

Platt, W.J., D.P. Ellair, J.M. Huffman, S.E. Potts, and B. Beckage. 2016. Pyrogenic fuels produced by savanna trees can engineer humid savannas. Ecology 86 : 352-372 https://doi.org/10.1002/ecm.1224.

Porter, E.E., and R.A. Redak. 1996. Short-term recovery of the grasshopper communities (Orthoptera: Acrididae) of a California native grassland after prescribed burning. Environmental Entomology 25: 987-992 https://doi.org/ 10.1093/ee/25.5.987.

Provencher, L., B.J. Herring, D.R. Gordon, H.L. Rodgers, G.W. Tanner, J.L. Hardesty, L.A. Brennan, and A.R. Litt. 2001. Longleaf pine and oak responses to hardwood reduction techniques in fire-suppressed sandhills in northwest Florida. Forest Ecology and Management 148: 1-15 https://doi.org/10.1016/ S0378-1127(00)00525-9.

Ries, L., R.J. Fletcher, J. Battin, and T.D. Sisk. 2004. Ecological responses to habitat edges: mechanisms, models, and variability explained. Annual Review of Ecology, Evolution, and Systematics 35: 491-522 https://doi.org/10.1146/ annurev.ecolsys.35.112202.130148.

Rose, E.T., T.R. Simons, R. Klein, and A.J. McKerrow. 2016. Normalized burn ratios link fire severity with patterns of avian occurrence. Landscape Ecology 31 (7): 1537-1550 https://doi.org/10.1007/s10980-015-0334-x.

Ryan, K.C., E.E. Knapp, and J.M. Varner. 2013. Prescribed fire in North American forests and woodlands: history, current practice, and challenges. Frontiers in Ecology and the Environment 11: e15-e24 https://doi.org/10.1890/120329.

Sisson, D.C., D.W. Speake, J.L. Landers, and J.L. Buckner. 1990. Effects of prescribed burning on wild turkey habitat preference and nest site selection in south Georgia. Proceedings of the National Wild Turkey Symposium 6: 44-50.

Still, H.R., and D.P. Bauman. 1990. Wild turkey nesting ecology on the Francis Marion National Forest. Proceedings of the National Wild Turkey Symposium 6: 13-17.
Swengel, A.B. 2001. A literature review of insect responses to fire, compared to other conservation managements of open habitat. Biodiversity and Conservation 10: 1141-1169 https://doi.org/10.1023/A:1016683807033.

Thaxton, J.M., and W.J. Platt. 2006. Small-scale fuel variation alters burn severity and shrub abundance in a pine savanna. Ecology 87: 1331-1337 https://doi. org/10.1890/0012-9658(2006)87[1331:SFVAFI]2.0.CO;2.

Varner, J.M., J.S. Kush, and R.S. Meldahl. 2000. Ecological restoration of an oldgrowth longleaf pine stand utilizing prescribed fire. Tall Timbers Fire Ecology Conference Proceedings 21: 216-219.

Wellendorf, S.D., and W.E. Palmer. 2006. Effects of two burn scales on northern bobwhite demographic parameters and home range size. In Gamebird 2006: Quail VI and Perdix XII, ed. S.B. Cederbaum, B.C. Faircloth, T.M. Terhune, J.J. Thompson, and J.P. Carroll, 271-281. Athens: Warnell School of Forestry and Natural Resources.

White, P.S., and S.T.A. Pickett. 1985. Natural disturbance and patch dynamics: an introduction. In The ecology of natural disturbance and patch dynamics, ed. S.T.A. Pickett and P.S. White, 3-13. San Diego: Academic Press https://doi.org/ 10.1016/B978-0-12-554520-4.50006-X.

Whittingham, M.J., P.A. Stephens, R.B. Bradbury, and R.P. Freckleton. 2006. Why do we still use stepwise modelling in ecology and behaviour? Journal of Animal Ecology 75: 1182-1189 https://doi.org/10.1111/j.1365-2656.2006.01141.x.

Wiggers, M.S., L.K. Kirkman, R.S. Boyd, and J.K. Hiers. 2013. Fine-scale variation in surface fire environment and legume germination in the longleaf pine ecosystem. Forest Ecology and Management 310: 54-63 https://doi.org/10. 1016/j.foreco.2013.07.030.

Wightman, P.H., J. Kilgo, M. Vukovich, J.R. Cantrell, C.R. Ruth, B.S. Cohen, M.J. Chamberlain, and B.A. Collier. 2019. Gobbling chronology of eastern wild turkeys in South Carolina. Journal of Wildlife Management 83: 325-333 https://doi.org/10.1002/jwmg.21600.

Wong, B.B.M., and U. Candolin. 2015. Behavioral responses to changing environments. Behavioral Ecology 26: 665-673 https://doi.org/10.1093/ beheco/aru183.

Wood, J.D., B.S. Cohen, T.J. Prebyl, L.M. Conner, B.A. Collier, and M.J. Chamberlain. 2018. Time-since-fire and stand seral stage affect habitat selection of eastern wild turkeys in a managed longleaf pine ecosystem. Forest Ecology and Management 411: 203-212 https://doi.org/10.1016/j.foreco.2018.01.033.

Wragg, P.D., T. Mielke, and D. Tilman. 2018. Forbs, grasses, and grassland fire behaviour. Journal of Ecology 106: 1983-2001 https://doi.org/10.1111/13652745.12980.

Yeldell, N.A., B.S. Cohen, A.R. Little, B.A. Collier, and M.J. Chamberlain. 2017a. Nest site selection and nest survival of eastern wild turkeys in a pyric landscape. Journal of Wildlife Management 18: 1073-1083 https://doi.org/10.1002/jwmg.21267.

Yeldell, N.A., B.S. Cohen, T.J. Prebyl, B.A. Collier, and M.J. Chamberlain. 2017b. Prescribed fire influences habitat selection of female eastern wild turkeys. Journal of Wildlife Management 18: 1287-1297 https://doi.org/10.1002/jwmg.21290.

Yeldell, N.A., B.S. Cohen, T. Prebyl, B.A. Collier, and M.J. Chamberlain. 2017c. Use of pine-dominated forests by female eastern wild turkeys immediately after prescribed fire. Forest Ecology and Management 398: 226-234 https://doi.org/ 10.1016/j.foreco.2017.05.003

Zhang, J., K.M. O'Reilly, G.L.W. Perry, G.A. Taylor, and T.E. Dennis. 2015. Extending the functionality of behavioural change-point analysis with $k$-means clustering: a case study with the little penguin (Eudyptula minor). PLOS ONE 10 (4): e0122811 https://doi.org/10.1371/journal.pone.0122811.

Zuur, A.F., E.N. leno, and C.S. Elphick. 2009. A protocol for data exploration to avoid common statistical problems. Methods in Ecology and Evolution 1: 3-14 https://doi.org/10.1111/j.2041-210X.2009.00001.x.

\section{Publisher's Note}

Springer Nature remains neutral with regard to jurisdictional claims in published maps and institutional affiliations. 